\title{
Inspiration and Insinuation Influences on Human Thinking and Behavior: A Psychoanalytical, Psychodynamic, and Cognitive Phenomenon
}

\author{
Jamal A. Badi ${ }^{1} \&$ Lukman A. Olorogun ${ }^{2}$ \\ ${ }^{1}$ Fundamental and Inter-Disciplinary Studies, International Islamic University Malaysia, Malaysia \\ ${ }^{2}$ College of Business, Universiti Utara Malaysia, Malaysia \\ Correspondence: Lukman A. Olorogun, College of Business, Universiti Utara Malaysia, Malaysia. E-mail: \\ yinluk2000@gmail.com; yinluk2000@yahoo.com
}

Received: June 19, 2015 Accepted: October 22, 2015 Online Published: November 20, 2015

doi:10.5539/ass.v11n27p71 URL: http://dx.doi.org/10.5539/ass.v11n27p71

\begin{abstract}
Is insinuation one of the most influential phenomena in the early and continuous development of human behavior? Yes. Does previous scientific study give ample of time to understand unconsciousness and its manifestation from this point of view? No. As we have demonstrated in the following pages, insinuation does hold a high view in the divine scriptures as an opposite to inspiration. The scientific views on unconsciousness theory further ascertained its influence on human activities. A number of scientists however, denounced this clear evidence due to lack of laboratory prove of inspiration-cum-insinuation effects rather termed unconsciousness. In this essay, through dedicated analysis using both induction and deduction methods we showed that their theories failed to study unconsciousness from a holistic perspective. It only focused on those that have psychological and psychopathological problems in exclusion of reasonable human beings, thus, contained numerous errors that even contradicted their scientific findings. Following in-depth and dedicated analysis, we showed the influences of unseen phenomena that are beyond human control from Islamic philosophy viewpoints affirming earlier biblical claims of insinuation influences. We concluded by mentioning some of the physical evidences justified by the Islamic scripture "Qur'an" and some of the implications of these findings for certain aspects of the contemporary "inspiration and insinuation debates".
\end{abstract}

Keywords: psychoanalysis, human memory, inspiration and insinuation, cognitive phenomenon, behavior

\section{Introduction}

In moving beyond Freud's legacy on human memory we can start to clarify conceptual profusion, not to say confusion, of the terms by adopting 'minimal' or restricted definitions in the first instance. Thus, human memory is basically defined or taken as a system controlled by sexual affections. And this idea manifest on the directions of researches on current psychopathology, neurosciences, cognitive sciences, and other related fields. Its expression would be either viewed as negative or positive, sound or unsound scientific viewpoints. It would be generally appealing to an average human being that Freud's idea had posed questions that time and circumstances will resolve. Number of scholars or writers willing or unwillingly have invested enormous energy to proof Freud's ideologies right or wrong.

From the above premises, we may then proceed, as a first step, to generally state that, there are three ideologies emerged from Frued's idea of memory. The first are group of scholars that subscribed to Freud's idea popularly known as Freudians. The second group of scholars is those known as psychodynamics and the last group is well known as cognitivists. Another classification is to group the theoreticians into psychoanalytic such as Brill, Frenkel-Brunswik etc. and non-Psychoanalytic theoreticians such as Adler etc. Between these two groups are numerous specializations such as clinical and nonclinical psychoanalysts, neuropsychologists, behavioral scientists etc.

There exist, a broad cross-cultural inter-relatedness among the above stated professionals. This conclusion is based on common trait which is significant in their existing surveyed literatures. Their efforts are devoted to understanding of human personality which has significant correlation with human development and growth. At a very least, most studies conclude that sound and correct information is the backbone for human development and 
growth. The information and its usage however, differ among these professionals. For the sake of brevity, through brief and conscience, we state the focuses of each group.

\section{Methods}

The researchers have adopted dedicated theoretical analysis through inductive and deductive qualitative method. With this procedure we arrived at a memory model that is thinking and behavioral model. The rest of the research is arranged as follows: human memory from professional views, followed by issues in personality development etc.

\section{Human Memory: Professionals' Perspectives}

A typical phrasing of the professionals' views is that psychoanalysis in this context is generalized regardless of different existing views of classical or modern psychoanalysis on personality studies. An implicit assumption is that psychoanalysis, by adequate understanding human reasoning process and controlling it generally can provide higher stability and as well growth and development rate.

Thus, the total Freudians are of the opinions that personality is largely motivated by sexual affections. Precisely, total Freudian theorists believed in conscious and unconscious processes, conflict and defenses, and the centrality of the sexual drives in the development of personality neurosis through three stages of human life i.e. infant, adolescent, and adulthood (Freud, 1910; Jahoda, 1977; Fonagy, 2000; Blatt \& Levy, 2003). Yet there is a counterargument that, put crudely, psychodynamic issues such as conscious and unconscious processes, conflicting forces are part of human life within the mind but do not necessarily depend on the idea of sexuality (Adler, 1929, 1939; Horney, 1950; Sullivan, 1953; Fromm, 1947, 1962; Jung, 1971; Powers et al., 2015).

Before we can conclude on how strong the relationship between human memory, consciousness and unconsciousness as well inspiration and insinuation, we need to examine the actual, extensive and endless intellectual debates in precise manner. Interestingly, one major shared ground is that personality can be influenced by internal or external phenomena. The internal phenomena can be evoked and controlled or spontaneous and beyond the control of the subject. Technically, personality (human behaviors) is either consciously where the agent (person) intentionally/knowingly executes the action and has power to direct its activities. Perhaps, it happened without and beyond the control of the agent (person) which is technically known as unconscious activities.

Similarly, external forces or phenomena do stimulate actions that can consciously or unconsciously affect the agent. Thus, further theorists such as Agnes Petocz stated that Freudians' and others' theory of internal phenomena is biologically determined and as such, unconscious associative formation which provide raw materials from which true symbols arise. In other words, Freudians' models can be identified through symbols (i.e. the agent's actions). It is justified to conclude that conscious or unconscious external activities as stated by Adler (1929, 1939) Horney (1950) Sullivan (1953) Fromm (1947, 1962) and Jung (1971) such as life experiences (social forces) like achievement, social motivation, striving for superiority etc. are determined according to the symbol, which emancipate from the agent and are the real personality. Bodas et al. (2015) research on effects of negative television contents on Israelis, the results showed that televised traumatic content and negative perception of broadcasts are directly associated increase of anxiety and psychopathology issues.

\subsection{Personality Development: Critical Issues}

Leaving aside the point of different narrations of personality development (obviously its "respect/accord" is essential to human existence) the gist of the argument is clear. Likewise, broad survey finds that "sexuality deprivation" is insignificance in human growth and development (Jung, 1971). Certainly, all these measurements are fairly crude and cannot sustain firm conclusions. There are also personality studies pointing to the opposite direction that there are a number of uncounted phenomena. Particularly, during clinical observations, which lead to object relation and attachment theories. This was as result of patients with haunted fears of dangers of intimate relationship with others and other mystical issues (i.e. external phenomena like unseen events). However, the classical psychoanalysts have regarded this as irrelevant and maintained that this action is result of actual deprivations from early childhood (psychic). With their consents to the relatedness and attachment theories, investigators have identified two fundamental dimensions of relatedness and self-definition as central for understanding of personality organization and personality development.

In general, we can conclude that personality development can either be positive or negative. Researchers such as Blatt and Levy (on positive side) further conceptualized personality development as based on two fundamental parallel developments. The first is the development of the capacity to establish increasingly mature and mutually satisfying interpersonal relationship. The second is self-definitional line which is the development of a 
consolidated, realistic, essentially positive, differentiated, and integrated self-identity. Other researchers' studies have revealed the negative effects of personality development by relatedness and self-definition. Relatedness side effects for example, are avoidance and insecure, anxious-resistance, dependent depression, seeking comfort. Likewise, the negative side effect can lead to resistance, avoidance, self-critical, and depression. Thus, it suffices at this junction to state that relatedness and self-definition theories of personality development have similar implications as psychopathology.

Regardless of the differences in the literature, there are numbers of common understanding among researchers. Their common grounds are that human personality is biological, natural, and an evolution, which spread through three stages of life (i.e. from infant, to adolescent, and adulthood). Defect in an infant up bringing such as lack of proper care from the caregivers surely will lead to some psychopathological related problems and would definitely have greater impacts in later personality development. In the same line, over pampering or over intimacy with caregivers also would lead to insecure and related psychopathological development. This is strong evidence that there are external influences like environment and context in personality development which researchers such as Steinberg and Avenevoli (2000) have scientifically proved. It is rational to state that there are good and bad sides of personality and both are motivated by seen and unseen phenomena and circumstances.

Interestingly, these rational efforts have totally ignored the religious propositions on influence of seen and unseen phenomena and circumstances in personality development. Often they termed it to be mystical. While the scientists claimed to have discovered this knowledge, religious institutions and individuals such as Willcox (1895) Clark (1972) Holmes (1981) Canale (1994) have proven the originality of Biblical content based on unseen influences on the mind of the relators. Willcox (1895) postulates that inspiration, which influenced the Bible, is beyond ordinary secularists' definition and understanding of inspiration. Willcox further states that God's deeds are two-sided one against the other such as good vs bad (for scientific claims of good and bad see Steinberg and Avenevoli's (2000) study on the role of context on development of psychopathology). Notwithstanding, some of the rationalists such as Thrash and Elliot (2003) supported the ideas of the theologians on inspiration as a psychological construct. Thus, if a subject is inspired good, sound personality would suffice, and insinuation is an opposite of doing well, which manifest in behaviors that are societal discomforts.

\section{Personality Development: Islamic Debates}

As evident in the previous sections, numerous researches and excellent intellectual debates were available on psychoanalytic and cognitive sciences as well as Biblical theology. Although, majority of the scientists rejected the theological arguments on inspiration or personality development but at least the theologians' efforts were recognized academically. Despite the Qur'anic status on personality development from unseen and seen influences (kindly see Al-Hashimi, 1996; Osmani, 2011; Salim \& Abdullah, 2014), there are limited or few traces of attempt to explore the Qur'anic views on psychological phenomena by the scientists. Similarly, Prophet Muhammad \{peace be upon him\} have enumerated the significant of these two behavioral phenomena even if they are going to reject it as they disputed the Biblical theology views. Therefore, this study explores the role, sources and influences of inspiration and insinuation in personality development and their impacts on society. Thus, we produce below a personality framework based on the Qur'anic and Sunnatic definition of personality. For example the Qur'an States:

The human personality witnesses and Him Who perfected it. And inspired it with knowledge of what is wrong for it and what is right for it: Indeed successful will be the one who purifies it, and indeed failure will be the one who corrupts it! (Al-Shams: 7-10)

Figure 1 below shows the above verse has a wider implication in human's personality development because it emphasizes on the souls as the genesis of personality. The Qur'an conditions that development of personality rest on its continuous and constant purifications. Purification is in the physical and spiritual context. Spiritual purification serves as cousin for mental developments. Physical development, however, relies on mental development. These analyses can be proven by scientific researches on functions of "hormones" in human development. Similarly, people with deficient personality such as imbeciles were reported to have improper structure of hormones and other vital mental stimulating organs in their body (kindly see Pamela Smith 2005). This further justifies the Qur'anic classification of two types of human personalities. The Qur'an demands Saying:

And give not unto the foolish your property which Allah has made a means of support for you, but feed them therein, and speak to them words of kindness and justice (Al-Nisa': 5)

Scientific definition of the foolish in the Qur'anic context is a person who cannot manage their affairs in a reasonable way. The foolish is believed to have some sorts of mental problem or something affecting his/her 
psychological structure. The Prophet \{s.a.w\} was reported to have said"

For every action there is a period of enthusiasm / activity, and for every period of enthusiasm / activity there is a period of rest / inactivity. So he whose period of rest / inactivity is in accordance with my Sunnah then he is rightly guided, but he whose period of rest / inactivity accords with other than this, then he is destroyed

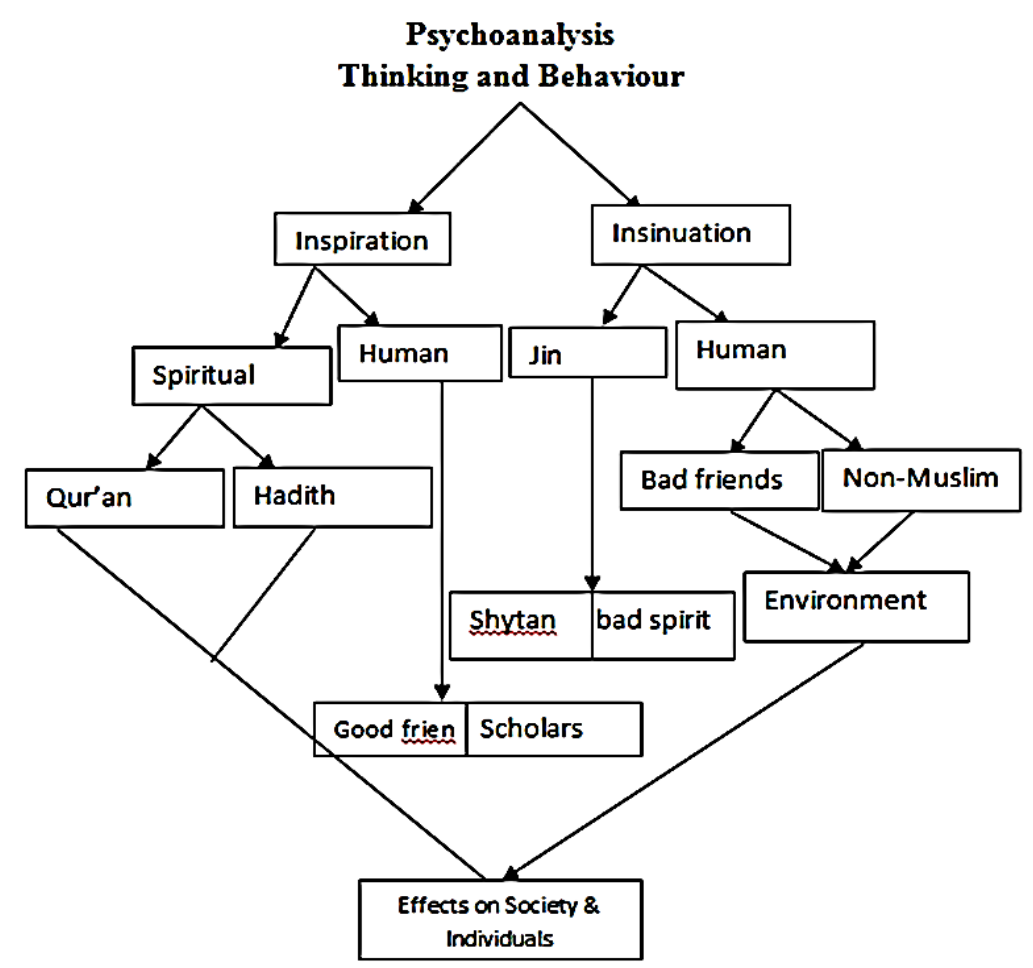

Figure 1. Islamic personality development framework

In this essay, we argue that inconsistencies and inadequateness in the literature on personality development and behavioral influences and consequences result in part from a lack of incompleteness of the theories. In other words, each theory viewed this phenomenon from narrow perspectives. In particular, we believed that extant study has failed either, theoretically or methodologically, to disentangle two different roles of unseen (unconscious) phenomena such as the roles which inspiration and insinuation play in personality development at all stages of development (i.e. infant, adolescent, and adulthood). Although, theoretical and empirical study of personality development points to the study of roles of consciousness and unconsciousness on characteristic and behavioral developments, no known theories have adequately unified the conscious and unconscious elements and the role of each of these processes or have included a comprehensive discussion of them. Instead, numbers of existing theories insinuate single or partial factors as being responsible for personality development. Furthermore, due to the cross-sectional, correlational, and retrospective nature of the scientific studies, it is not possible or it is extremely difficult to discern the total or specific factors generally acceptable that can be from the causes that serve to maintain, deteriorate, or exacerbate a particular style of personality.

Accordingly, it is the case that some theories show relatively cover of wider contents (albeit modest) such as the Freudians' view on sexuality role on personality. Likewise, Thrash \& Elliot (2003) on inspiration as a psychological construct and Steinberg \& Avenevolit (2000), Chefetz, (2015) on role of context on psychopathology, it is not clear whether for example sexual arousal of an infant who is yet to realize his existence is an inspiration or insinuation phenomenon. The constant failure of researchers (scientists) in their theories and models to recognize the religious, either Biblical or Qur'anic, viewpoints on personality development and behavioral development has contributed to the muddied and unimpressive state of their literatures.

We offer here series of observations and hypothesis about the significance of inspiration and insinuation on conscious and unconscious phenomena. We use the term inspiration and insinuation broadly in the context of 
Islamic philosophy and referring to the good and bad side of human characters/behaviors in personality development as prevalent in the society. Our argument is that inspiration and insinuation are the mechanism that powered individuals' personality and they can be controlled if properly managed in accordance to Qur'anic and Sunnatic (Prophet's traditions) prescriptions. In particular, we hypothesize that the role of Qur'anic and Sunnatic personality models would be enough in preventing and curing of psychopathological issues. This is because most disturbing part of societal relationship is the psychopathology aspect of personality.

Before turning to the central argument advanced in this essay, a few introductory comments are of demand. First, due to the space limitation of the essay, we excluded extensive review of literature and provided only an overview with exemplary citations for provoking alternative research questions and direction. Second, we use the term psychoanalysis and psychodynamic, psychopathology, and cognitive science in their broadest form (theoretical and clinical). While we recognize that there are differences between these wide professions, our intent is to formulate some general propositions about roles of inspiration and insinuation on human psychic that apply across these professions. Third, given our interest in inspiration and insinuation influences, we focus on those forms of psychopathology and non-psychopathology that are presumed to have a substantial contribution, such as studies under the broad headings- internal and external unconsciousness. We do not focus on genetically inherited issues.

Finally, we recognize that the distinctions we draw from inspiration-insinuation and biology are to some extent non-empirical. The individual's natural system is not fixed with fastener (i.e. something that cannot be change), however, it is genetically oriented that can be influenced in response to inspirational or insinuation phenomena. By the same sense, the individual's inspiration and insinuation is not wholly an objective reality that is completely independent of the person, because inspiration and insinuation according to Islamic ideology is perceived, selected, and modified by the individual. Nevertheless, it is important to distinguish between internal and external inspiration as well as internal and external insinuation. This is because they are believed to influence biological issues.

\section{Trends in "Inspiration" and "Insinuation" in Eliciting Personality}

While scientific traditions of learning and scholarship have arguably been presented, in the past, as exclusivist and confined to small circles of scientists and their empirical certainties, religious entities -individuals and institutions- contributions on scientific proofs have been viewed as mystical phenomena. However, well-known theologians, for example M. A. Willcox, Fernando L. Canale, Gordon Clark, Michael W. Holmes have shown, however, that inspiration is a sort or source of knowledge that is not unfamiliar with the 'transmission' of messages from the God to the receiver and that most Prophets were communicated to through this means particularly the revelation of the Bible. Scientifically, at least, Todd M. Thrash and Andrew J. Elliot (2003) also theorized that inspiration is a sort of psychological construct or better, the inspiration and insinuation of human as being part of evolution where group behavior and role and origin of spirituality evident in Freud's theory. Even the British historian, Thomas Carlyle, (1841) recognized inspiration as one of the major traits of great men (hero) personality. In addition to this, Eckmann's accounted personal experience of unconscious development of great men personality without knowing how and when she imbibed such as an act.

For the sake of brevity, it is crystal that from religious viewpoint human were chosen to convey the holy Words (i.e. God's messages) through inspiration. In other word, inspiration is a means of communication by God to humans. One shortcoming of the theologians' literature was that inspiration was limited to Biblical viewpoints and in proof of the inherence of the Bible as Words and Book of God (Thrash \& Elliot, 2003). However, from the scientific and historian perspective, inspiration was viewed as an inheritance or even genetic (Thrash \& Elliot, 2003). Notwithstanding, it is obvious that inspiration is a vital core of personality and behavioral developments. Furthermore, those that are inspired mostly are modest. In essence, inspiration related to good (see Dahl \& Stengel, 1978; Thrash \& Elliot's, 2003; and Steinberg \& Avenevoli's, 2000). While the literature was very supportive in proving the influence of inspiration, its contrast (i.e. if one is not inspired, the opposite will surely suffice) "insinuation" had been given little or never been giving adequate attention such as those given to conscious and unconscious phenomena personality and personality and behavioral developments.

The results of inspiration have been identified as positive and societal acceptable personality development in human (Davitz, 1969; Dahl \& Stengel, 1978; Watson et al., 1988; Thrash \& Elliot, 2003). However, the results of psychopathology have never been associated with insinuation. This is partly because most psychopathological researches are strictly scientific, particularly clinical observations and clinical data from patients treated. Currently, United Nations' (UN) reported that in every 40seconds, someone in the world commits suicide. The same report on psychopathology indicate that 1-4 children suffer madness that lead to suicide with Sweden 
having highest rate of suicide among young people. The report also indicated that happiness, unhappiness, richness, or poverty is not necessarily sources of psychopathology or suicide. Accordingly, the World Health Organization (WHO) estimated 6Trillions U.S. dollars as costs of mental health by 2030. This estimation was based on the WHO's report that 1million mental diseases lead to death yearly. In addition, happiness report showed $20 \%$ of adolescents between ages 15-19 reported to have suffered depression in 2013. Compounding the problems, the reports pointed out that by 2020 depression would be leading cause of disability. At this junction, these reports begged for some questions: Is it all the psychopathological behavior or acts are due to deficiencies in health? Or genetically heredity? Or do younger people in depression hold higher responsibilities than their parents or the adults? Thanks to the UN's reports, it is obvious that other unforeseen or unconscious events such as insinuation might perhaps have something to do with such acts or personality in general. Thus, the next sections would deal with inspiration and insinuation in detail according to Islamic philosophy with justification from existing literatures.

\section{Inspiration and Insinuation in Islamic Philosophy}

When traditional psychoanalysts, psychodynamics, and cognitivists considered inspiration as ordinary intelligent (see Willcox, 1895) and its opposite as psychopathology (Blatt \& Levy, 2003), they totally ignored other interpretation such as the spiritual interpretation and termed it as mystical (Bowlby, 1969). In the same thought, insinuation has never been considered as a phenomenon.

Islamic behavioral science ('Ilmu al-Sulouk) on the contrary is based on heart management. Thus, human heart is the center of human activities and serves all purposes of psychoanalysis, psychodynamic, and cognitive sciences. The Qur'an recognizes the heart as the center where good and bad arises "Surely Allah does not blind the eyes but blindfold the hearts in the chests" (Qur'an 22: 46). In this verse, it is evident that real seeing begins from the heart and that it is the capacity to "comprehend" or "understand". Comprehension is the center paradigm of personality. The word "reasonable human" "reasonable personality" though may be subjective and has been defined, and standardized through literature of psychoanalysis, psychodynamics, psychopathology, and cognitive science over decades. This will be dealt with in next section. Recently neuroanatomical findings indicate that the heart is center of human functions. They further showed that the heart has much neuron than human brain and as such, the brain cannot function in isolation of the heart. Hence, the Qur'an says " $[\ldots]$ that which whispers in the hearts of the mankind** from the spirit and the mankind" (Qur'an 114: 6).

Recalling the arguments of the conventional behavioral sciences in general, the Freudians believed conditions such as sex and aggressions are fundamental human instincts from which other motives emerged. To be fair to the Freudian, adequate analysis would justify this conclusion. Human beings' sexual urge can be reasonable or acceptable (i.e. in line with societal norms) or unreasonable sex. Reasonable (excluding religious laws) sexual activities can be with someone's lawfully married wife or with non-married (in modern term girlfriend, consensual sex or others in as much is not under pressure or forceful). In other words, sexual activities must be between man (male) and woman (female) on the one hand. On the other hand, unreasonable or unacceptable sexual activities are same sex e.g. gays and lesbians' copulation. In other words, a sexual desire toward someone who has same features has been described as psychopathological problem. Similarly, aggressions can be positive or negative. A positive aggression often has been behind most of worldly achievements. The aggression of the Prophets such as Jesus to eradicate the Jewish usurious dealing is a good aggression to institute equality in among the people. Thus, one of the leadership traits is pro-activeness. Contrarily, aggression as described by the Freudian is that which lead to social problems like killings, fighting and other violence activities to one's life or others etc.

The psychodynamics over ruled sexuality as sources of human activities but agreed that human being do engage in unconscious activities i.e. that they cannot imagine the motivation for it such as suicide, lesbians and gays sexual drives. This includes forceful sexual activities such as rape etc. In another interpretation, conflicting forces within the mind can lead to vices such as murder (when psychopath mistaken human for animal and when a man assumes he is woman and thus, must have sex with another man), logical errors, and category errors of various types. Aggression can accompany either case. Likewise, these behaviors or personalities are social vices regardless whether they were perpetrated aggressively or gently. There is no society that declares, "Binge drinking", that led to marital conflict (where the husband battered his wife and children after drunk), murder, disorders, depressions, suicide, or breakage as reasonable or a standard personality. It might even lead to civil commotion.

Furthermore, the cognitive and other behavioral scientists such as social cognitive believed that personality measure is based on affect and cognitive-affect interactions. In simple terms, humans are rationale naturally and 
are somehow influenced by the structure of the environment they exist. In other words, activation of cognition is capable of knowledge or conscious, which influence level of behavior or personality. Thus, outcome of personality is introverts, liberal etc. Their ideas excluded natural phenomena and the other devilish nature of human being. It is intrigued however, that the cognitive scientists agreed on external influences on behaviors and personalities. The debates continue and arguments erased arguments between the psychoanalysts, psychodynamics psychopathologists, and cognitive scientists.

Critical observation of the above arguments shows that efforts to study human behavior and personality transformed from Freudian ideology of sexual influences but unconsciously executed, followed by those that believed that conscious and unconscious influences are behind human personality and those that regarded biological problems influences and lastly those that concluded that environments and other things influence personality and behavior. In our personal perspectives, all the scholarships worth accreditation but their limitations are due to lack of perfection, inefficiency, and incompleteness of human intellectual capacity in addressing issues in a holistic ways. Each of these groups addressed a single issue out of many issues of human behavior and personality and discussed it according to their personal comprehensions and clinical observations. The Freudians' view of sexuality is fundamental to all vices. Similarly, the psychodynamics idea of conscious and unconscious influences is excellent. Likewise, the cognitive scientists' idea of external influences on building of human personality is to some extent right scholarship. Our conclusions are based on Islamic behavioral science arguments. At this junction, it is important to point out that the Western or conventional discourse of personality or behavioral sciences began around $19^{\text {th }}-20^{\text {th }}$ centuries i.e. over 200years ago. On the contrary, Islamic behavioral science had been enshrined in Islamic philosophy over 1400 years.

One of the popular traditions of the Prophet \{peace and blessings be upon him \} hints on human personality at birth. This tradition was reported through numerous chains. It affirmed that human beings are generally born on the right part i.e. total submission and obedient to Allah's wills. The tradition read thus: Abu Hurairah narrated that, the Prophet \{peace and blessings be upon him\} said: there is no one delivered to this world except on this righteousness. However, his parent might turn him to a Jew or Christian as the donkey is licked to shape ....[...] (Muslim/4806). This tradition justifies the claims that human behaviors can also be influenced by other factors than biological illnesses.

Thus, the human personality or behavioral standard or deficiency begins from the heart. The deficiency or standard can be instigated from biological viewpoints or external influences (conscious and unconscious) such as societal influences. Figure 2 explicitly shows symbiotic relationship. Furthermore, the influences on this heart are of two types according to a tradition of the Prophet \{peace and blessings be upon him\} that read thus, "Surely, al-Malak (The Angel) has al-Lammat (influence) and the Shaitan (Satan) has al-Lammat (influence). The influences of the Angel encourage in doing good and give glad tidings i.e. positive influences and the Shaitan (Satan) influences encourage in doing evil and disregards or contempt on truth" i.e. negative influences. This Prophetic tradition originally stated as follows:

On the authority of Ibn Mas'ud \{may Allah be pleased with him\} who said: the Prophet said: surely the Satan has influence over the sons of Adam and the Angel has influence: however, the influence of the Satan is seeking refuge with evil doing and lying with the truth. Nevertheless, influence of the Angel seeking refuge with good deeds, and witness the truth. He who witness any of this "Angel influence" he/she should know he is with Allah. Nonetheless, he who witnessed the other side should seek refuge against Satan. Then he recites "The Satan promises you with poverty and ordering you to commit fornication....." (Related by al-Tirmidhi as strange and good)

Al-Lammat al-Malak" (The Angel's influences) is interpreted as "inspiration" and "al-Lammat al-Shaytan" (the Satan's influences) as "insinuation". In another tradition reported:

On the authority of Abu Hurayrah (may Allah be please with him), the believer is a mirror for the believer, and the believer is the brother of the believer. He safeguards his property for him and defends him from behind.

The Qur'anic verse and these hadith (prophetic traditions) can be well understood through the figure below: 


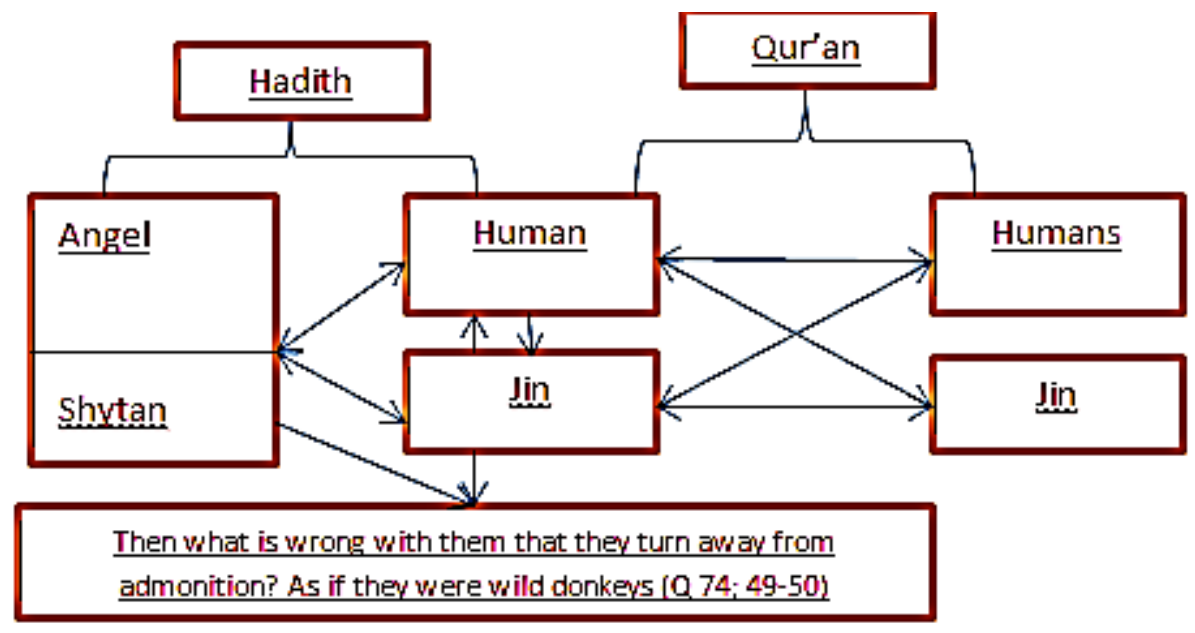

Figure 2. Insinuation of seen and unseen phenomena

The Qur'an further indicates "The Shaytan (Satan) threatens you with poverty and orders you to commit Fahisha (evil deeds, stealing, extortion, exploitation, illegal sexual intercourse, sins etc.) [...]" (Qur'an 2: 268). For example, rapists are unconsciously influenced to develop a desire for women beyond their scope either by the rejection or other social class deficiencies to forcefully engage their victims in an unwanted sex. If the victim resist it might lead to her death. Thus, Freud's claims of sexuality as genesis of psychopathology surfaced but neglected the social class influences where a crime is committed because the perpetrator desires to belong to a certain social context as propounded by Steinberg and Avenevolit. It was concluded that Shaytan derives best of humans by threats of loss or scarcity of worldly and material benefits that are limited in utilities, scope and life span. Axiomatically, (among believers and atheists) death is an end to all enjoyments and agonies of worldly materials. Yet, humans are threatened by deficiency in things that are not perpetual as death. The end is fighting among individuals, states, robbery, cheating, exploitations, slavery and other forms of infringing harms on other earth's inhabitant particularly fellow human beings in order to satisfy one's canal desires. Fear of poverty is partly influenced by concern of what people in the environment or community might say about one's life achievements. In another word, individuals fear of being relegated or classified as poor in their communities. These mostly lead human beings to go extra length or by any means to become recognized in their families and communities such as Israeli striving to gain Palestinians' recognitions and acceptance of Jewish State by killing millions of innocent human beings.

In another tradition narrated in the interpretation of the Qur'anic verse, which says: "Those that distance themselves from major sins and filthiest (illegal sexual intercourse) except the small faults" through various chains such as Abi Hurairah and Ibn Abbas that said "the small faults is al-Zina (filth). In the same light, another tradition pointed out "the first group of al-Lammat is al-Fawahish (unauthorized kissing, romance, illegal sexual intercourse, extortions and exploitations etc.). The second part of Qur'an 2: 268 says "Allah promises you Forgiveness, Bounty, Allah is All-Sufficient for His creatures' needs, All-Knower". The interpretation of "Bounty" in this verse expressed and extended over all humans' betterments.

The diffusion of above expressions to personality or behavioral issues is based on exclusion of health or biological deficiencies. For example, one who is threatened by poverty is easily be tempted to steal or cheat (by either arm or fraudulent activities). In Freud's argument, aggression is the result of such a threat. In psychodynamic expression, one can unconsciously take wrong action to eliminate the threat violently or by other means. From cognitive scientists' view of poverty, environment would determine the kind of personality a person could be or behavior pattern of such a person. In reality poverty is evident, however, someone can resolve poverty without resulting to violent, stealing, fraudulent activities etc. This is why the Qur'an indicates that the Satan's insinuation is colorful "Tazyin" (ornament or decorate) i.e. the Satan designed his works in a fashionable manner that is pleasing and appealing to human heart. For instance, having sex with different people (having new taste daily) is a pleasure that is pleasing to both man and woman and stealing or frauds are shortcuts to becoming rich or acquiring properties. Then the Satan whispers this to the heart as an advice (which is negative) such as rape the girl, kill the person, steal their property etc. and unconsciously the subject act on this advice. Immediately the act has been committed, most of the time, the person would definitely realize the error from his 
side. Exemption to this general expression is those with pathological problems such as mental diseases or other neurological problems.

The insinuation act stated above is said to be manifested through the environment and other elements in the environment such as friends, technology etc. The Qur'an specifically states "the Shayatin (Satans) of human and that of jinn advices themselves [...]" (Qur'an 72: 6). Therefore, human being is always being accompanied by both conscious and unconscious accomplices. Behavior or personality would always been defined according to these accomplices with exemption of people with mental or neuropsychological disorders. The Qur'an and Prophet's traditions have taken care of their positions.

\subsection{Internal and External Unconsciousness}

Unlike consciousness which happened in the framework of knowledge of the cause and effect, unconsciousness however, is activities that happened and occur without the individuals' knowledge of the cause and effect. In the shadow of this premise, unconscious acts are like gambling where loss and/or gain outcome is unknown but share equal probability/chance. Thus, unconscious activities bring about good "benefit" or bad "loss". Motivations of unconscious acts are internal or external. The internal unconscious stimulators can be known phenomena such as psychopathological or neuropsychological issues or unexplainable phenomena. The perpetrators of the unconscious acts have no capacity to control or manage the situation they found themselves. In essence, the situation or circumstance manipulate their unawareness to manifest itself.

The most important to our current discussion is the negative unexplained phenomena which are regarded as vices. These vices are of two types as described by the Qur'an "the Shayatin (Satans) of human and that of jinn advices themselves [...]". Shayatin (Satans) in this verse were generally classified into humans and the spirits. This verse was further supported by the tradition "hadith Mawquf" cited earlier i.e. "Surely, al-Malak (The Angel) has al-Lammat (influence) and the Shaitan (Satan) has al-Lammat (influence). The influences of the Angel encourage in doing good and give glad tidings i.e. positive influences and the Shaitan (Satan) influences encourage in doing evil and disregards or contempt on truth" i.e. negative influences.

Recent conclusions of the psychodynamics such as Adler, Jung Horney, Fromm, and Sullivian further grounded the first part of the Qur'anic verse that "human" in their term "social forces" which includes human influences are the genesis of personality. In the context of the Qur'an, human influences can be positive or negative. If the environment or society is occupied by ethically (such as abstinence from human sacrifices) mannered inhabitants, which is technically known as "norms", definitely personality of those in that community would be reasonable and beneficial attitudes manifested through their behaviors that are positive influences on the one hand. On the hand, a community occupied by unethical vices that are considered evil or devilish in all forms such as alcoholic consumptions (according to the Qur'an verse stated earlier), human sacrifices etc. the personality would be shaped according to the dominant characteristics that are negative influences. Thus, the Qur'anic verse had disposed this concept over 1400 centuries ago before the contemporary psychodynamic (human effect) concepts of cause and effect to human behavior.

The true life positive human influence or social influences on personality development was demonstrated in one of the American's juvenile prison "Camp Kilpatric". The influence of the head coach "Sean Porter" on the rehabilitation of the kids involved. If Porter was a devilish individual, the inmates would have been further destroyed than one can imagine. The testimony of "Jason Lamb" on his personal transformation from a social destroyer to normal human being was an amazing account. Therefore, behavioral development is based on the influences of social activities that one was exposed. These include both acceptable and unacceptable social activities.

We argue that psychodynamic views ignored the other side of life which is evident in social relationships. The acclaimed mystical "according the scientists" parts of social relations would have been given some considerable attentions. This is where the Qur'anic verse emphasizes "Jinn" (Santan) influences on personality development. Hartmann et al. (1946) agreed that cognitive development is based on motivational forces such as human influences (social forces) that harnessed and employed by structures of thought automatically powered. In a simple statement, unconsciousness is powerful machinery in human personality development. Automaticity of thought followed by action where individuals have no control of its outcome cannot be overriden in cognitive discuss. Thus, unconscious actions that resulted in social vices such as a gun triggered unknowingly or murdering of innocent community member could be triggered by unexplainable phenomena. In fact, Hartmann et al. (1946) claimed that impacts of automaticity of thought process on cognitive development and adaptation is a familiar discourse among contemporary psychologists.

Again in the Camp Kilpatric account, most of the inmates claimed they could not account for the influences that 
drove their devilish and destructive attitudes and behavior. The real life account such as stealing, killing, rape etc. of the teenagers at the camp testifies that actions emancipated from "unknown sources" which is above their control. However, among things that are likely to compound their predicaments are the three processes of cognitive development that is, input, process, and output. Badi \& Olorogun $(2012 ; 2013)$ have empirically demonstrated impact of each of this process in behavioral compositions using Muslims as a case study. Earlier, Bowlby (1969) had discussed input, process, and output as stages of life experiences. Positive input would results in positive process and eventually positive and inspirational output would suffice. On the contrary, negative input would flow on negative/erroneous process and finally lead to different kinds of social destructions Various models of measuring aspects of cognitive sciences have been developed over time (see Gigerenzer 1992).

\subsection{Legal and Provisions: Individual and Population Approach}

The medical provisions for all psychopathological problems are largely based on individual approach. Individuals are considered having different experiences that necessitate different medical or psychological treatments. Similar cases are treated in isolation of the public. The psychologists approach are limited and based on the case presented to them. Hence, provisions of curing psychopathological issues are clinically limited. The population nevertheless, is not without pathological problems that are less or beyond clinical treatments. In order to address the enormous level of various pathological issues at population levels, the governments impose limits on their citizens. These limitations are designed according to the aims and objectives of the state as designed by the same human beings with at least one or more pathological problems. Whether their pathological problems are evident or non-noticeable, the impositions of jail terms and other deterrence systems are eminent which are mostly politically motivated and implemented. To favor a group of people over others is a psychopathological problem such as the preferability of the first world over the third world nations and inhabitants at international level. Locally, the Cast system of the Hindus religion is a class of psychopathology acclaimed under religious dictates.

In the case of inequalities at the international levels, no psychological clinical and theoretical have ever considered such an act as pathological problems. Similarly, the Hindus Cast system at least among the Hinds has never been seen as pathological problem. In contrast, the Nigerian customary law of awarding paternity to the bride price provider was recognized as "repugnant policy (Note 1)" and was termed under the English common law as unreasonable, naturally unjust, unequitable and outright unacceptable. To those that practiced the repugnant policy, it was reasonable (Onuoha, 2008). These scenarios are clinically incurable. Even wrong policies i.e. politically motivated policies of individuals and states have never being diagnosed clinically, nonetheless, theoretically addressed by another fairly induced psychopath through claimed research findings or otherwise (kindly see Ahonen et al., 2014 about hidden context and invisible power on diversity). The vicious circle of pathological problems continues indicating that humans are limited in all forms including setting of standard of behavior. Conclusively, all human attempts to deal with psychopathological problems lead to invention of another state of pathological problems to be solved by the generations to come (see Michel Foucault's 1961 translated by "Richard Howard 1964" Madness and Civilization on how Europeans dealt with Middle Ages psychopathological problems).

The Qur'an however, provides last long solutions to both individuals and population psychopathological problems. As stated by Ahonen et al. (2014) that was a result of human beings natural power relation internalized by individuals, as well as those that guide the behavior of population "biopolitics". In our words, it means that human beings are naturally inclined to be excessive or inaccurate in all their dealings. The Qur'an provides consequences for individuals' actions and collective repercussions for a community inaccuracy. These provisions liberates humans from domination of individuals with specific aims and objectives such as human's developed laws and regulations and as well as standards of life. This is evident in several verses in the Qur'an such as

And to Allah belongs all that is in the heavens and all that is in the earth, that He may requite those who do evil with that which they have done (i.e. punish them in Hell), and reward those who do good, with what is best (Paradise)** Those who avoid great sins (See the Qur'an 6: 152-153) and Al-Fawahish (illegal sex intercourse and others) except the small faults,- verily, your Lord is of Vast Forgiveness. He knows you well when He created you from the earth (Adam), and when you were Fetuses in your mother's wombs. So ascribe not purity to yourselves. He knows best him who fears Allah and keeps his duty to Him (the pious) (Qur'an 53: 32-33).

The verses above well express the autonomy of The Creator over all that humans claimed to have possessed or acquired. Expressly, He never judge only by actions rather in conjunction to the inner and both conscious and 
unconscious aspects which is highly determined by submission to His dictates. Allah promised to requite the evil doers i.e. those deliberately perpetrate great sins i.e. "Major Sins" which Qur'an has stated clearly in earlier Chapter. Similarly, He shall reward those who do well "good" and follows His parts. However, on both sides the law is relaxes "except small faults". This phrase indicates that human beings are never being free of committing sins or wronging one another unconsciously through insinuation which is beyond their control. For Allah's retributions are on those who knowingly acted in contrary to the standard that governs the world (by revelations "Qur'an or "Bible" or Taorah). Furthermore, Allah confirms that He knows humans more than they understand themselves. Therefore, no man should praise her/him of purity because the inner part of humans is the essence of livelihood. The Qur'an further expresses in another verse

If you human beings abstains from "Major Sins" that you were restricted from, We shall erase your shortcomings "those that you committed through insinuation" and We shall abode you in dignity (Qur'an 4: 31$)$.

The verse above states clearly condition of overlooking humans' shortcomings. Abstaining from Major Sins necessitate the forgiveness of the minor sins. In addition to that is the reward of abode in dignified manner. These two Qur'anic injunctions are enough to reshape characters and behavior of humans towards their Creator and amongst themselves.

\section{Conclusion}

The accounts in this essay indicated at least theoretical effect of unconscious activities that are beyond human control from both religious and conventional perspectives. The conventional literature has dealt with almost all that related to psychopathology save insinuation effects was given limited attention or totally ignored. There are consensuses among the believers such Muslims, Christians and Jewish as well as other religions that humans are limited in all ramifications and can be insinuate to commit acts that are not intended. Likewise, the religious Texts such Qur'an, Bible, Taorah are there to mediate human excessiveness in their dealings amongst themselves and their Creator. In this essay however, basic attempt was to ground theory on insinuation which had attracted rejections from scientific viewpoints. Nonetheless, the discussions mainly justified the presence and effects of insinuation on human behavioral development from Islamic philosophy viewpoints. We recommend an empirical study or application of this theory in future research.

\section{References}

Adler, A. (1929). The Science of Living. Garden City, New York: Doubleday.

Adler, A. (1939). Science Interest. New York: G. P. Putman.

Ahonen, P., Tienari, J., Merilänen, S., \& Pullen, A. (2014). Hidden context and invisible power relations: A Foucauldian reading of diversity research. Human relation, 67(3), 263-286. http://dx.doi.org/10.1177/ 0018726713491772

Al-Hashimi, M. A. (1996). In N. Al-Khattab (trans.) The Ideal Muslimah: The True Islamic Personality of the Muslim Woman. KSA, Ryadh: International Islamic Publishing House. Retrieved June 5, 2015. http://www.islamweb.net/.../The\%20Ideal\%20Muslimah\%20Muslim\%20personali

Anderson, J. R. (1991). Is human Cognitive Adaptive? Behavioral and Brain Sciences, 14, 471-517.

Badi, J. A., \& Olorogun, L. A. (2012). The Impact of Islamic Religious Schema on the Muslims and their Behaviour. International Journal of Arab Culture, Management and Sustainable Development, 2(4), 318-343.

Badi, J. A., \& Olorogun, L. A. (2013). Effects of Priming on Muslims' Behaviors: An Empirical Study. International Journal of Applied Science and Technology, 3(8), 21-27.

Blatt, S. J., \& Levy, K. N. (2003). Attachment Theory, Psychoanalysis, Personality Development, and Psychopathology. Psychoanalytic Inquiry: A Topical Journal for Mental Health Professionals, 23(1), 102-150.

Bodas, M., Siman-Tov, M., Peleg, K., \& Solomon, Z. (2015). Anxiety-Inducing Media: The Effect of Constant News Broadcasting on the Well-Being of Israeli Television Viewers. Psychiatry, 78(3), 265-276. http://dx.doi.org/10.1080/00332747.2015.1069658

Bowlby, J. (1969). Attachment and Loss: Volume 1. Attachment. New York: Basic Books.

Brill, A. A. (1949). Basic Principles of Psychoanalysis. Garden City, New York: Doubleday \& Company Inc.

Canale, F. L. (1994). Revelation and Inspiration: The Classical Model. Andrews University Seminary Studies, 
$32(1-2), 7-28$

Clark, H. (1972). Hamilton's Theory of Language and Inspiration. Journal of the Evangelical Theological Society, 15(1), 39-51.

Davitz, J. R. (1969). The Language of Emotion. New York: Academic Press.

Chefetz, R. A. (2015). Ten Things to Consider on the Road to Recognizing Dissociative Processes in Your Psychotherapy Practice. Psychiatry, 78(3), 288-291. http://dx.doi.org/10.1080/00332747.2015.1069660

Foucault, M. (1961). Folie et Déraison: Histoire de la folie à l'âge classique. In R. Howard (1964 trans.), Madness and Civilization: A History of Insanity in the Age of Reason. New York: Vintage Books.

Frenkel-Brunswik, E. (1954). Meaning of Psychoanalytic Concepts and Confirmation of Psychoanalytic Theories. Scientific Monthly, 79, 293-300.

Freud, S. (1910). The Origin and Development of Psychoanalysis. With Raymond E. Fancher Introduction and Commentary. American Journal of Psychology, 21, 181-128.

Fromm, E. (1947). Man for Himself. An inquiry into the Psychology of Ethics. New York: Holt, Rinehart \& Winston.

Fromm, E. (1962). The Sane Society. Greenwich, CT: Fawcett Books.

Gigerenzer, G. (1992). Discovery in Cognitive Psychology: New Tools Inspire New Theories. Science in Context, $5(2), 329-350$.

Gordon C. (1972). Hamilton's Theory of Language and Inspiration. Journal of the Evangelical Theological Society, 15(1), 39-51.

Hartmann, H., Kris, E., \& Loewestein, R. (1964). Comments on the Formation Psychic Structure. Psychoanalytic Study of the Child 2, 11-38.

Holmes, M. W. (1981). Origen and Inherency of Scriptures. JETS 24, 3, 221-231.

Honey, K. (1950). Neurosis and Human Growth. New York: Norton.

Jung, C. G. (1971). In J. Campbell (Ed.), The Portable Jung. New York: Viking.

Onuoha, R. A. (2008). Discriminatory Property Inheritance Under Customary Law in Nigeria: NGOs to the Rescue. International Journal of Not-for-Profit Law, 10(2). Retrieved August 1, 2014, http://www.icnl.org/research/journal/vol10iss2/art_4.htm

Osmani, N. M. (2011). Contemporary Issues in Qur'an and Sunnah Studies (1st ed.). Kuala Lumpur: IIUM Press.

Petocz, A. (1999). Freud, Psychoanalysis, and Symbolism. U.K.: The Press Syndicate of the University of Cambridge.

Salim, S., \& Abdullah, S. F. (2014). The Contemplative Intelligence in the Quran and Sunnah and Its Role in Knowledge Acquisition. International Journal of Asian Social Science, 4(3), 407-421.

Smith, P. (2005). Comprehensive look at Hormones and the effects of Hormone Replacement. Paper presented at 14th Annual International Congress on Anti-Aging Medicine, Orlando, Fla. Retrieved June 5, 2015, www.a4m.com/assets/pdf/bookstore/aamt_vol7_41_smith.pdf

Steinberg, L., \& Avenevoli, S. (2000). The Role of Context in the Development of Psychopathology: A Conceptual Framework and Some Speculative Propositions. Child Development, 71(1), 66-74.

Sullivan, H. S. (1953). The Interpersonal Theory of Psychiatry. New York: Notton.

Thrash, T. M., \& Elliot, A. J. (2003). Inspiration as a Psychological Construct. Journal of Personality and Social Psychology, 84(4), 871-889.

Watson, D., Clark, L. A., \& Telleng, A. (1988). Development and Validation of Belief Measures of Positive and Negative Affect: The PANAS Scales. Journal of Personality and Psychology, 54, 1063-1070.

Westen, D., Gabbard, G. O., \& Ortigo, K. M. (2008). Psychoanalytic approaches to personality. In O. P. John, R. W. Robins, \& L. A. Pervin (Eds.), Handbook of personality: Theory and Research (3rd ed., pp. 61-113). New York: Guilford Press.

Wilcox, M. A. (1895). Theories of Inspiration. The Biblical World, 5(3), 169-180. 


\section{Note}

Note 1. This scenario was all about how humans failed to view things in the same direction. Therefore, special intervention must be provided which create status for population when dealing with one another. Such a need is the role of revealed book such as the Qur'an has provides. For more on reasonableness of thinking and unconscious actions of Africa traditions particularly Nigeria see Reginald Akujobi Onuoha "Discriminatory Property Inheritance Under Customary Law in Nigeria: NGOs to the Rescue, The International Journal of Not-for-Profit Law, Volume 10, Issue 2, 2008. http://www.icnl.org/research/journal/vol10iss2/art_4.htm

\section{Copyrights}

Copyright for this article is retained by the author (s), with first publication rights granted to the journal.

This is an open-access article distributed under the terms and conditions of the Creative Commons Attribution license (http://creativecommons.org/licenses/by/3.0/). 